\title{
Situated modelling in the drawing workshop for bobbin lace
}

\author{
Maria Christine Werba Saldanhar, ${ }^{\mathrm{a},}$, Juliana Donato de Almeida \\ ${ }^{a}$ UFRN- Federal University of Rio Grande do Norte, Campus Universitário, Lagoa Nova, Technology Center, \\ Production Engineering Programme-PEP, Room 48, CEP: 59.072-970, Lagoa Nova, Natal, RN, Brazil. Tel/fax: + \\ 55 (0xx84) 8770-7861. Email: cwerbasaldanha@gmail.com
}

\begin{abstract}
The current article presents the process of situated modeling in the drawing workshop for bobbin lace developed and implemented in the Núcleo de Produção Artesanal Rendeiras da Vila, in Ponta Negra, Natal-Brasil. The workshop aimed to rescue the domain over the product in the production of bobbin lace through capacitation of both experienced and novice craftswomen. The modeling of the drawing workshop was grounded on the sociotechnical construction and in the concepts of anthropotechnology and also social technology. The modelling required an intense process of social construction involving the members of GREPE-UFRN (Group of extension and Research in Ergonomics) and the lacemakers od the community. The domain of drawing the lace has enabled the expression of the craftswomen creativity, increasing the amount of works and the sustainable development, thus reducing the risks of extinction of such art in the Village of Ponta Negra.
\end{abstract}

Keywords: situated modelling, Sociotechnical Construction, Drawing workshop, Bobbin lace,Artisan production

\section{Introduction}

Artisan activity is an important part of popular culture and a great trigger of development, many times being the only option of income generation for some families. The handicraft market has on average 8,5 million people in Brazil, 3,5 out of whom (40\%) live in the north-east. It is estimated that the sector moves nearly R \$28 Billion a year, which represents approximately $2,8 \%$ of GNP - Gross National Product, outnumbering the income generated by national industries such as clothing (2,7\%) and beverages (1\%) [16]. The quality of brazilian handicraft has caught the attention of the international market in the last years. In 2006, according to data from the Agency of Investiment and Exportation Promotion - APEX, Brazil exported R\$1,41 million in handicraft. [17] However, even having the support of institution, the cooperatives, associations and craftsmen themselves found difficulties to keep their production, either for the uneven actions, difficulty in absorbing new technologies/knowledge in the development of new products or very little or no sales skills. [9]

Bobbin lace is defined as traditional handicraft and is a kind of thread formed by weaving thread with the help of bobbins (A spool or reel that holds thread or yarn for spinning, weaving, knitting, sewing, or making lace), guided by fixed patterns on a pillow and which contain the drawings of the piece.( Fig. 1 and 2) The production of bobbin lace is a slow processt though the pace is intense and requires knowledge, concentration and, most of all, dedication.

\footnotetext{
${ }^{*}$ Corresponding author. E-mail: editorial@iospress.nl. Check if the checkbox in menu Tools/Options/Compatibility/Lay out footnotes like Word 6.x/95/97 is selected if you make a footnote for the corresponding author.
} 


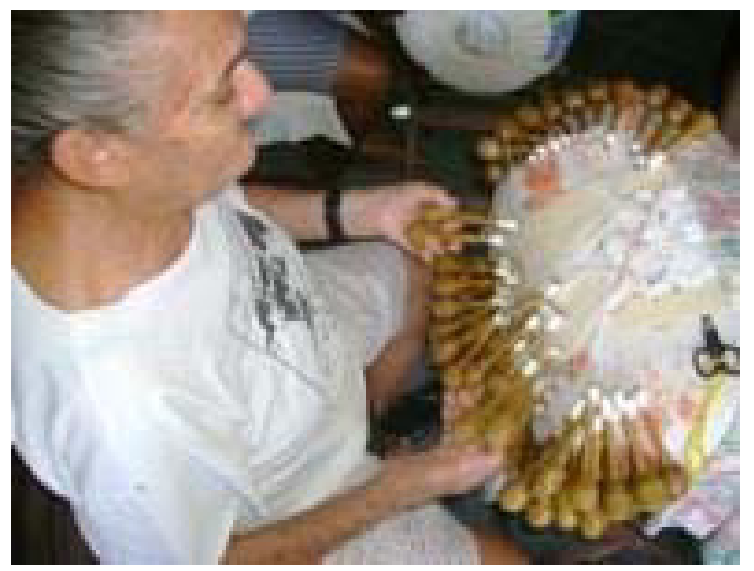

Figure 1: Bobbin Lacemaker

The basic threads of bobbin lace are known as traça, pano and trança (Fig. 2) which are combined to create several drawings produced and reproduced using one or several colors (Fig. 3) The main products are skirts, dresses, edges, table cloths, tray cloths, table runners. Though its diverse composition of weaving and colors, the most traditional products made by the lacemakers haven't suffered innovations, and most times will not follow any market trend or demand [12].

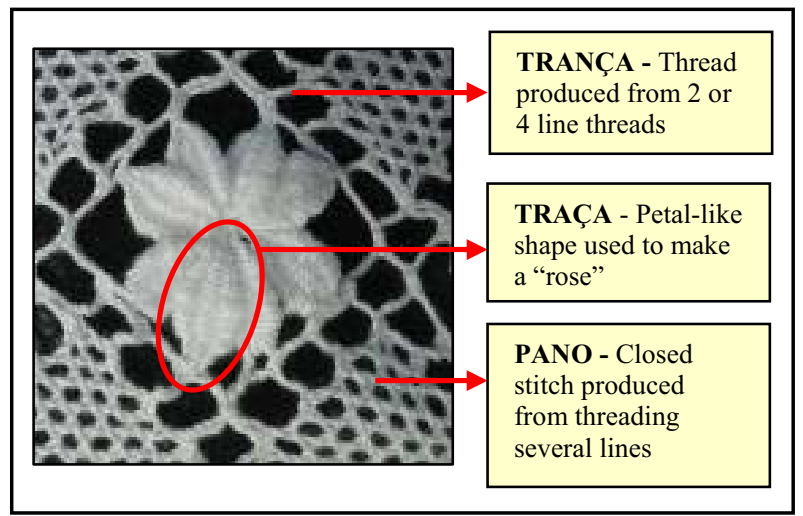

Figure 2: Bobbins lace detail

The production of bobbin lace in the Vila de Ponta Negra was already one of the most important means of generating income for some families. However, throughout the time with the rising uninterest of new generations in learning the practice, due mostly to the production time, difficult sales and insufficient financial return, devaluation of the product and craft activity. [11]

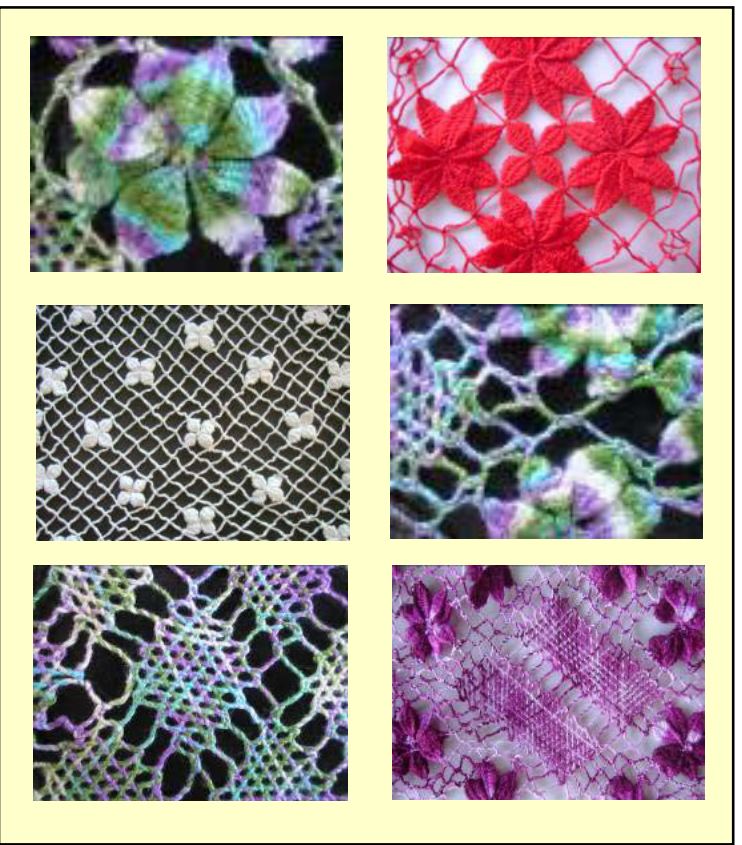

Figure 3 - Compositions with the weavings of bobbin lace

The attempt to mantain the job in the Vila de Ponta Negra, onde of the eledest lacemakers created in 1998 The Center of Artisan Production Rendeiras da Vila. It was located in a space next to her home, where the practice is performed in a cooperative way. Among the members of the Center, 07(58,3\%) are experienced lacemakers who have been active for over 50 years and only three(25\%) for less than 40 years. They have expertise on the production process but they did not dominate the product drawing, which made it difficult to inovate products, as stated:: "For the drawings we always ask for help, because I don't know how to draw very well a whole piece. I also didn't study a lot, mind you. But I ask for my sons when I want a drawing and they help me to draw, my eleder son, my youngest son or my daughter" (lacemaker of the Center, 59 years,member of the GF-1). Five crafswomen (41\%) said they could copy from other drawings or laced piece, but none of them knew how to create new patterns. "...when I started lacing there were drawings already, so I just picked them and copied, the same way I do it nowadays. I don't draw, I just "prick" (copy from another laced piece by pricking a cardboard shape)"(Lacemaker of the Center, 74 years old, member of the GF-1, GA, GS) It is important to highlight that the drawing made over a shape enlarges the failures of the original piece and demands knowledge and experience in the 
technique of lacing and reading the drawings [11$12,2]$.

It is believed that the collection of drawings inherited from acestors and which are still being used though being very worn, may still have influenced current lacemakers not to learn that step of the process. However, the fact that they don't dominate the technique of drawing has caused a partial loss on the domain over the product, which represents a limitation in the ability to innovate thus making them dependent on third parts who are not always able do draw faithfully to product conceived by the craftswoman. On the other hand, the fact that they do not fully dominate the lace drawing also makes it difficult to pass on the weaving technique in terms of reading the drawings and placing the bobbins in the early stage of production.

The project Bobbin Lace Drawing Workshop described in the current article is part of the Research and Extension Program Bobbin Lace School Workshop, which aims to rescue the domain of the product and production of bobbin lace thought the conception and implementation of a methodology of passing on the drawing technique of bobbin lace aiming to qualify the lacemakers. It was used the theoreticaland methodological approach ergonomics and situated ergonomics [8-22,20] and also anthropotechnology [721,23 ], which highlight the need to know local reality, habits, culture and work activity in order to identify its real demands thus allowing the correct intervention.

The modelling of the Drawing Workshop has occurred in a real work situation ( traditional artisan production) and features the single combination of organizational aspects ( context, tradition, culture, work organization), technological (means of work) and personal (competences, experience, scholarship, values, individual culture) envolved in the activity of work which is developed in a given context(Vila de Ponta Negra-Natal-RN). It is characterized by the cooperation and participation of the several actors involved in a process of social and technical construction [7-20,10], in which it was aimed to consider the specific reality of this craftswomen community and incorporate the singular experiences lived by these people, valuing the culture and tradition and their social economical organizational and cultural context.

It is intended to, through the conception and implementation of the method of teaching/learning the lace drawing to promote the qualification and to allow the expression craftswomen creativity, through the conception of new patterns and products in bob- bin lace, thus aiming to promote the sustainable development and reduce the risks of extinction of the job in the Vila de Ponta Negra.

\section{Methodology}

The demand of the drawing workshop features a provoked demand, process in which some potential demands or hypothetical demands are led to be organized, after carrrying out a previous analysis over the work of interest in the study because of theoretical research (estate of the art) and/or an analysis of a referential situation (estate of practice) in which some hypothesis are raised over the work that is intended to be studied. [3-10-4-20,15]. The methodology was constructed from the research within the community of lacemakers and is related to the desire/need of some lacemakers of drawing and producing new products, disconnecting the conception of new products from both external gents and consultancies so that the innovation of products may be achieved by the artisans themselves.

The modelling of the Drawing Workshop required an intense process of Social Construction [7-20,10], understood as the structuring of a sustenance device for ergonomic action, that is, the constitution of a team which comprehends all individuals that participate in the several moments of the modelling process, both the ones directly responsible by the intervention, technical support and decision-making and also the ones who take part in raising the information, restitutions and validations which permit the knowledge over the activity and its context, indispensable for the construction of an anthropotechnical solution.(Figure 4, Table 1)

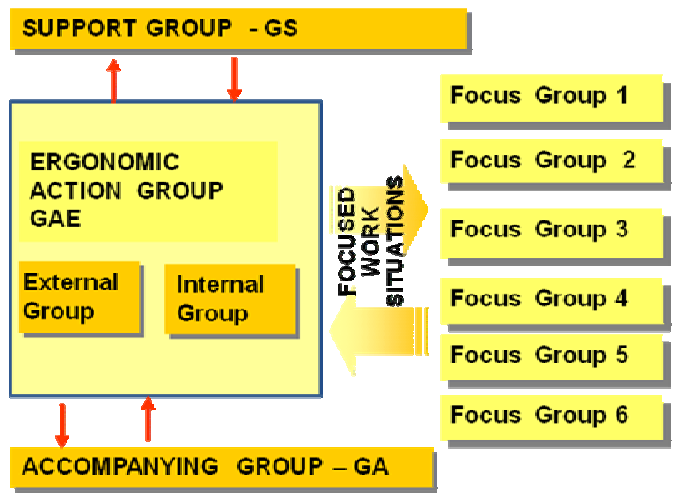

Figure 4: Social Construction in the Lace Bobbin Drawing Workshop 
Table 1

Group Constitution of Social Construction in the Lace Bobbin Drawing Workshop

\begin{tabular}{|c|c|}
\hline Groups & Characteristics \\
\hline $\begin{array}{l}\text { Group of } \\
\text { Ergonomic } \\
\text { Action } \\
\text { GAE }\end{array}$ & $\begin{array}{l}\text { People who have knowledge over the } \\
\text { process, techniques and methods in ergo- } \\
\text { nomics and specific knowledge in the act- } \\
\text { ing area of the Project. It has external } \\
\text { members to the community of lacemakers } \\
\text { (two industrial designers, masters in pro- } \\
\text { duction engineering) and also internal } \\
\text { members (lacemaker tutor of the drawing } \\
\text { workshop and mentor of the Bobbin Lace } \\
\text { Workshop methodology) }\end{array}$ \\
\hline $\begin{array}{l}\text { Supporting } \\
\text { Group } \\
\text { GS }\end{array}$ & $\begin{array}{l}\text { People who have the power of managerial } \\
\text { decisions either along with the Production } \\
\text { Center, where the the project is being im- } \\
\text { plemented ( leading lacemakers of the Pro- } \\
\text { duction Center), the Group of Research and } \\
\text { Extension which is develping/coordenating } \\
\text { the project (coordenator of the project and } \\
\text { mater students advisor), or the the coorde- } \\
\text { nation of the financing agent. }\end{array}$ \\
\hline $\begin{array}{l}\text { Accompaning } \\
\text { Group } \\
\text { GA }\end{array}$ & $\begin{array}{l}\text { People who have technical authority to take } \\
\text { decisions related to the drawing workshop } \\
\text { related to both the ergonomic and anthropo- } \\
\text { technical methodology (inner cooderna- } \\
\text { tor/advisor) and the range of the lacemak- } \\
\text { ing job (lacemaker tutor and leader) }\end{array}$ \\
\hline $\begin{array}{c}\text { Focus } \\
\text { Groups } \\
\text { GF }\end{array}$ & $\begin{array}{l}\text { People who took part in the collecting of } \\
\text { data, restitutions and validations in deffe- } \\
\text { rent moments of the situated modelling and } \\
\text { its implementation. GF 1: Experienced } \\
\text { Lacemakers Center; GF 2: Lace Workshop } \\
\text { Tutors; GF 3: Apprentice Lacemakers in } \\
\text { the Lace Workshop; GF 4: Drawing Work- } \\
\text { shop Instructors GF 5: Students of Drawing } \\
\text { Workshop - Experienced LAcemakers; GF } \\
\text { 6: Students of Drawing workshop - Lace- } \\
\text { making Apprentices }\end{array}$ \\
\hline
\end{tabular}

The situated modelling of the drawing workshop supported by the social construction process [7-10,4], has used bibliographical and documental researches, research in reference situation [6], situated research and progressive validations [15]. It was used interactional methods and techniques (conversational action, spontaneous and provoked verbalization hearings, application of dynamic scripts and social economical questionaires, collective validating sections and observational methods and techniques ( systematic observations helped by voice recordings, films and photographs) [20], for both the focused and reference situation.
- Biblliographical and documental research: Technical information collected about bobbin lace ( books, dissertations and scientific articles), as well as photographs of products, shapes and weavings, aiming to get a better knowledge over the activity of weaving and drwaing the lace patterns. Among the materials researched, it is important to highlight the Master Dissertation which explored the Design Workshop implemented in the area of the study [2].

- Preliminary situated Research: Carried ou in the Center of Artisan Production, through observational methods (product observation, drawings and activity) and interactional methods (free speeches and verbalizations). It aimed to know the steps of bobbin lace production, which is very important to the development of the workshop for besides allowing the continuous contact of the members of GAE, GF1, GS and GA groups it also reinforced important aspects such as the construction of reputation and trust [10].

- Research in Reference Situation (Lace workshop):The analysis of the Lace Workshop [5] carried in the Production Center aims to pass on the technical knowledge of bobbin lace production as an internal reference situation. It allowed the experience of the master students in the learning of the lacing techniques for they took part in the workshop along with the students allowing mutual knowledge exchange, easy and difficult parts of the lace teaching method developed by the GAE lacemaker member therefore helping the understanding of the contrasts, variabilities and regulations faced by instructors and students allowing the identification of characteristic situations prone to happen in the drawing workshop and, as a result, the search of alternatives to deal with such variables.

- Conception of the Pilot version of the Drawing Workshop: The first version, a conceptual model, consisted on the conception of modules and their contents elaborated by the GAE and discussed with the members of GA (Accompanying group) and GS( Supporting group) from the bibliographical and documental researches and the preliminary situated analysis. From the initial purpose and the results of referential situation analysis, it was carried the detailing and description of the modules, specifying contents, methodology and techniques to be used, and which were discussed and validated with the Accompanying and Supporting group. The pilot version 
of the workshop consisted on the detailing of exercises to be used in the first step of the workshop: trace the thread (to square) and six exercises in growing order of complexity where the elements of the weaving are drawn in the squared fabric from patterns specially conceived for the workshop from old pieces.

- Implemented version of the Drawing Workshop: The next step consisted on the implementation of the workshop for a group 14 lacemakers, including experts and apprentices (GF 5 and 6) in the facilities of the Artisan Production Center of Vila de Ponta Negra. The workshop was given twice a week ( 8 hours/week) for 12 months. (Picture 5) The workshop was taught by different tutors, including the GAE lacemaker- who took part in the design of the lace and drawing workshop, the experienced senior lacemaker of the Center (who is also part of the workshop students group), another experienced lacemaker from Vila de Ponta Negra and the master student of GAE who has a degree in Industrial Design.

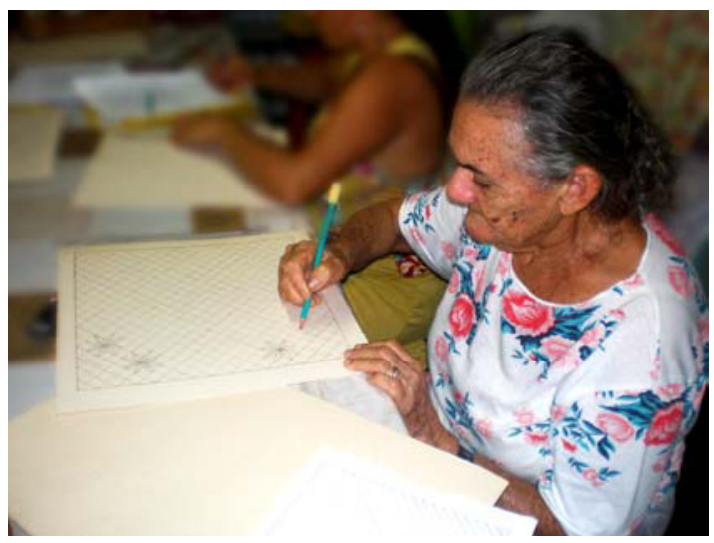

Figure 5: Bobbin Lace Drawing Workshop

- Situated analysis and appreciation of implementation: during the implementation of the workshop, some adjustments were made in the methodology in order to adequate it to reality, once it has a heterogeneous group of skilled lacemakers (GF5) and apprentices (GF6) in which limitations and capabilities were observed. The situated analysis was done through observational methods ( class observation with video and photo records) and interactional methods (spontaneous and provoked verbalizations and collective analysis). Several aspects were analysed, such as doubts and difficulties found in the exercise completion, facilitating aspects and suggestions for improvement. In that sense, some previously designed exercises were modified or eliminated and others were added, repetition of exercises at home for fixing, among others. In the end of each module, a collective analysis was done in which the technique of self confrontation was used- images (photos and films) related to the exercise were shown for participants to comment and suggest improvements. As a result of the collective analysis, some regulations were introduced in the following modules. The data collected during the workshop were analysed and tabled through the comment inclusion matrix in order to collaborate in the mode Progressive validations: in the modeling of the methodology of the Drwaing Workshop, progressive validations were made so that it was possivle to adjust the method in a progressive and situated way [15]. According to [10], "the practice of restituting and validating the analysis of collected information from the workers in an ergonomic intervention, besides being an ethical issue, it can constitute a moment of correction and complementation from the criticism and comments by workers in the area of the restitution device.'lling process and in the development of proposal of adapted ergonomic recommendations, reaching a Workshop model that is more adequate to the lacemakers' needs.

- Progressive validations: in the modelling of the methodology of the Drwaing Workshop, progressive validations were made so that it was possivle to adjust the method in a progressive and situated way [15]. According to [10], "the practice of restituting and validating the analysis of collected information from the workers in an ergonomic intervention, besides being an ethical issue, it can constitute a moment of correction and complementation from the criticism and comments by workers in the area of the restitution device."

In this case, restitutions and validations of methodological information occurred throughout the process, both in the conception and the implementation, aiming to keep a work dynamic in which several focus groups that participated in the research have contributes through periodic meetings, free speeches, spontaneous and provoked verbalizations, besides observations made in the work situation, following and participating in the conception process [10]. 


\section{Results}

The results of the Project Workshop of Drawing for Bobbin Lace are situates on two levels: a broader level and a more focused one.

On a broader level, the results of the project have an abrangence related to the cultural aspects of artisan production. It is emphasized the development of a methodology focusing the teaching of a drwaing techinque from bobbin lace, a very important step in the process of the formation of lacemakers for it allows the domain of the product allowing the autonomy for the creation of new products and a bigger domais the process, which refers to the reading of patterns and the initial positioning of the bobbins. The methodology developed may be used in the formation of lacemakers in the actual localtion or in others, besides helping to serve as a basis for the development of methodologies for other artisan typologies.

Testimonies of the lacemakers made in the collective sessions of validation and evaluation in the methodology assure the validity of the methodology: "If I had started (making lace) together with the drawing, surely I would be doing a blouse or a skirt..."( Apprentice lacemaker - GF6), "I was still blind. I can only see now. I say blind for lacemaking, for now I know what a card is (referring to a pattern), I know what it is. So, I already have the notion that if I take a cart and draw I will draw, for I am aware of what I am doing. Before I was not aware, I was blind.(...) It's different, before I didn't have that, I would go with my eyes closed. It has opened my miund." (Student of the drawing workshop, Apprentice lacemaker - GF5)

On the more focused level, the results refer to the scope of the project, complementary to the formation of lacemakers thus qualifying them in the drawing technique for bobbin lace and the modelling of pieces, allowing the conception and developing new patterns of drawings and products. In that sense it is emphasized: Qualification of 13 (thirteen) bobbin lacemakers; Qualification of lacemakers in the communitiy as an instructot; Creation of a personal collection of drawings and the increase in the collective estate of the Center Of Artisan Production, including the reproduction of old drawings.

For rescuing old drawings, it is important to reinforce de donation of drawings produced by elder lacemakers in the Vila de Ponta Negra, some of them already deceased. Some drawings were deteriorated with the traces almost erased so it was necessary the help of more experienced lacemakers to read the drawings from the holes in the joints of the weavings.

Drawings, patterns and products from the Workshop can be divided in: - exercises (10 different patterns for each student, addind up to 114 exercises done); - reproductions of old patterns (95 reproductions of old drawings) and; - creation of new patterns (73 new patterns). During the workshop 24 new products were created from the new drawings. Four months after the end of the workshop it was observed that they continued creating new drawings, the conception of new patterns and the development of new products following innovative aspects.

On the other hand, the qualification of a lacemaker as a tutor in the community and the infrastructue ( pillows, frames, bobbins, chairs, etc) set on the occasion of the project of the Center of Artisan Production Rendeiras da Vila allows the continuing of the functioning of the Bobbin Lace School and Workshop, disconnecting the workshops from the action of supporting organs and external consultancies - becoming an alternative of income generation for the tutor lacemakers; the reactivation of a net of handicraft economic activities linked with bobbin lace, such as pillow making, bobbins and frams, thus promoting an alternative income generation for the Center and for the Vila de Ponta Negra, which strengthens the activity and reduces its risk of extinction.

\section{Analysis and Discussions}

The process of situated modelling used in the conception of the methodology for the Workshop of drawing for bobbin lace is recommended and emphasized by ergonomics, anthropotechnology and macroergonomics when they discuss the delicate role of technology interventions and transference. It is emphasized that such interventions must be constructed along with the actors envolved in the process, including several groups in the reception community (GS, GA, GF's) with external groups in a process of social technical construction which respects its economical, social, organizational and cultural aspects.

The ergonomic analysis preconizes and effectives the social and technical construction and therefore is fundamental to the modelling of the Drawing Workshop, once it allowed to deal the construction of a participative social device. As a result we can estate that the construction of technical 
and social relationships that allow the aknowledgement of reality os situated and contributes to the development of anthropotechnically adequate and sustainable solutions.

\section{References}

[1] Almeida, J.D., 2010. Modelagem situada de uma atividade tradicional: o caso da oficina de desenho de renda de Bilros em Ponta Negra. - Natal, RN. Dissertação (Mestrado em Engenharia de Produção) GREPE/PEP/UFRN, Natal 184f.

[2] Barros, K.S. 2009 Análise Antropotecnológica do desenvolvimento de novos produtos na produção artesanal: Caso das Rendeiras de Bilro da Vila de Ponta Negra, em Natal-RN. Dissertação (Mestrado em Engenharia de Produção) GREPE/PEP/UFRN, Natal. $168 \mathrm{f}$.

[3] Carvalho, R.J.M, Saldanh,M.C.W. Relatório de Instrução da Demanda. CESERG,GENTE/COPPE/UFRJ, 2001.

[4] Carvalho, R.J.M.de. A padronização situada como resultante da ação ergonômica em sistemas complexos: estudos de caso numa companhia aérea nacional a propósito da implantação de um treinamento CRM-LOFT. Tese (Doutorado em Engenharia de Produção). Rio de Janeiro: COPPE/UFRJ, 2005.

[5] Cordeiro, 2010 Rendeiras Da Vila de Ponta Negra: a continuidade da tradição através do ensino. Dissertação (Mestrado em Engenharia de Produção) GREPE/PEP/UFRN, Natal

[6] Daniellou, F. Métodos e ergonomia de concepção: a análise de situações de referência e a simulação do trabalho. In: DUARTE, F.. Ergonomia e projeto na indústria de processo contínuo. Rio de Janeiro: COPPE/UFRJ: Lucerna, 2002, p.29.

[7] Daniellou, F. A ergonomia em busca de seus princípios: debates epistemológicos. São Paulo: Edgard Blucher, 2004. $244 p$.

[8] Guérin, F. et al. 2001. Compreender o trabalho para transformá-lo: a prática de ergonomia. São Paulo: Edgard Blucher Ltda. 195 p.

[9] Leal. M de L. Produção Artesanal: Análise do Método de Intervenção de Design no Artesanato Potiguar sob ponto de Vista dos Atores Envolvidos no Processo. Dissertação (Mestrado em Engenharia de Produção) GREPE/PEP/UFRN, 2011. Natal.
[10] Saldanha, M.C.W. 2004. Ergonomia de Concepção de uma plataforma Line Oriented Flight Training (LOFT) em uma companhia aérea Brasileira: A relevância do Processo de Construção Social de Projeto. 2004. 243 f.. Tese (Doutorado em Engenharia de Produção) - UFRJ, Rio de Janeiro.

[11] Saldanha, M.C.W. 2006. Projeto Rendeiras da Vila: alternativas de sustentabilidade da renda de bilro na Vila de Ponta Negra. Projeto de Pesquisa e Extensão. GREPE/PEP/DEP/UFRN.

[12] Saldanha, M.C.W., 2007 Rendeiras da Vila: Desenvolvimento de Novos Produtos com Renda de Bilro: alternativa para evitar a extinção da arte, promover o desenvolvimento sustentável e resgatar a cidadania na Vila de Ponta Negra. (Projeto de Pesquisa e Extensão). GREPE/PEP/DEP/UFRN. Natal-RN, 2008

[13] Saldanha, M.C.W. 2008. Oficina Escola de Renda de Bilro. Projeto de Pesquisa e Extensão. GREPE/UFRN.

[14] Saldanha, M.C.W. 2009. RENDEIRAS DA VILA: Oficina Escola de Renda de Bilro. Relatório do Projeto de Extensão PROEXT CULTURA. GREPE/UFRN, $27 \mathrm{p}$

[15] Saldanha, M.C.W.., Almeida, J.D., Cordeiro, A.D., Cavalcante, P. 2010.Modelagem situada da Oficina de Desenho de Renda de Bilro. In: Cultura e Extensão Universitária: democratização do conhecimento. Onça, L.A., Camargo, E.D., Piero, A. (organizadores). São João Del ReyMG, Malta., p. 203-216.

[16] SEBRAE. Termo de Referência de Design. Brasília: SEBRAE, 2006

[17] SEBRAE. Artesanato: um negócio genuinamente brasileiro. Vol 01. Nº 01 . Brasília: SEBRAE, 2008

[18]Thiollent, M. J. M. 2002. Metodologia da pesquisa-ação. 12. ed. São Paulo: Cortez.

[19] Vidal, M.C.R. 2002Ergonomia na Empresa: Útil, Prática e Aplicada. Rio de janeiro: Virtual Científica.

[20] Vidal, M.C.R. 2003. Guia para Análise Ergonômica do Trabalho (AET) na empresa: uma metodologia realista, ordenada e sistemática. Rio de Janeiro: Virtual Cientifica.

[21]Wisner, 1994. A. A Inteligência no Trabalho: Textos selecionados de Ergonomia. São Paulo: Fundacentro.

[22] Wisner, A.1987. Por dentro do trabalho: ergonomia método e técnica. São Paulo: FTD/Oboré.

\section{Fomentation:}

CNPq, PROEXT Cultura, PROEX-UFRN, Bolsas de mestrado CAPES e CNPq e de extensão PROEX-UFRN 